\title{
The PAX2 Transcription Factor Is Expressed in Cystic and Hyperproliferative Dysplastic Epithelia in Human Kidney Malformations
}

\author{
Paul J.D. Winyard, ${ }^{\star}$ R. Anthony Risdon, ${ }^{\ddagger}$ Virginia R. Sams, ${ }^{\S}$ Gregory R. Dressler, ${ }^{\|}$and Adrian S. Woolf* \\ ${ }^{*}$ Developmental Biology Unit, Institute of Child Health, University of London, London WC1E IEH, United Kingdom; ${ }^{\ddagger}$ Department of \\ Histopathology, Hospital for Sick Children, London WCIN 1JH, United Kingdom; ${ }^{\S}$ Department of Histopathology, University College \\ Medical School, London WC1E 6JJ, United Kingdom; and ${ }^{\|}$Department of Pathology, Howard Hughes Medical Institute, University of \\ Michigan Medical Center, Ann Arbor, Michigan 48109-0650
}

\begin{abstract}
Human dysplastic kidneys are developmental aberrations which are responsible for many of the very young children with chronic renal failure. They contain poorly differentiated metanephric cells in addition to metaplastic elements. We recently demonstrated that apoptosis was prominent in undifferentiated cells around dysplastic tubules (Winyard, P.J.D., J. Nauta, D.S. Lirenman, P. Hardman, V.R. Sams, R.A. Risdon, and A.S. Woolf. 1996. Kidney Int. 49:135-146), perhaps explaining the tendency of some of these organs to regress. In contrast, apoptosis was rare in dysplastic epithelia which are thought to be ureteric bud malformations. On occasion, these tubules form cysts which distend the abdominal cavity (the multicystic dysplastic kidney) and dysplastic kidneys may rarely become malignant. We now demonstrate that dysplastic tubules maintain a high rate of proliferation postnatally and that PAX2, a potentially oncogenic transcription factor, is expressed in these epithelia. In contrast, both cell proliferation and PAX2 are downregulated during normal maturation of human collecting ducts. We demonstrate that BCL2, a protein which prevents apoptosis in renal mesenchymal to epithelial conversion, is expressed ectopically in dysplastic kidney epithelia. We propose that dysplastic cyst formation may be understood in terms of aberrant temporal and spatial expression of master genes which are tightly regulated in the normal program of human nephrogenesis. (J. Clin. Invest. 1996. 98:451-459.) Key words: BCL2 • dysplastic kidney • nephrogenesis • PAX2 • WT1
\end{abstract}

\section{Introduction}

Development is orchestrated by regulatory genes expressed in a temporal and spatial cascade (1). Many such genes encode transcription factors that must first bind to, and then regulate the expression of, growth factor, cell adhesion, and also other

Part of this work (concerning BCL2 expression) was presented as a poster at the 28th American Society of Nephrology meeting in San Diego in 1995.

Address correspondence to Dr. Adrian S. Woolf, Senior Lecturer in Developmental Biology, Developmental Biology Unit, Institute of Child Health, 30 Guilford Street, London WC1E 1EH, UK. Phone: 1712429789 x2217; FAX: 171831 4366; E-mail: a.woolf@ich.ucl.ac.uk

Received for publication 26 March 1996 and accepted in revised form 15 May 1996.

J. Clin. Invest.

(C) The American Society for Clinical Investigation, Inc.

0021-9738/96/07/0451/09 \$2.00

Volume 98, Number 2, July 1996, 451-459 transcription factor genes (1-3). One transcription factor family contains the DNA-binding "paired" domain and is encoded by $P A X$ genes (4), of which nine members have been identified in humans (5). Drosophila homologues control embryonic patterning (4) and cell specification (6), while a zebrafish $P A X$ gene is implicated in retinal development (7). Expression patterns and functional ablation experiments show that mouse $P A X$ genes regulate development of the brain, eye, lymphoid system, musculature, neural crest, thymus and vertebrae (8-12). Other studies reveal PAX overexpression causes cell transformation and tumor formation (13). In humans, familial and sporadic human mutations in $P A X 3$ and $P A X 6$ are associated with Waardenburg syndromes $(14,15)$ and aniridia (16) respectively, while rearrangement of $P A X 3$ causes soft tissue tumors (17).

Two $P A X$ genes are relevant to nephrogenesis, $P A X 2$ and $P A X 8(18,19)$. Mouse PAX2 is expressed in the mesonephric duct and its branch, the ureteric bud which gives rise to ureteric, renal pelvic and collecting duct epithelia. Both PAX2 and PAX8 are expressed in mesenchymal/epithelial conversion during nephron formation. These genes are downregulated as the kidney matures (18-20) but transgenic overexpression of PAX2 causes epithelial hyperproliferation and cyst formation (21). Conversely, genetic ablation of a single $P A X 2$ allele causes renal hypoplasia $(9,22)$ while antisense oligonucleotides, which reduce PAX2 protein in organ culture, inhibit the mesenchymal to epithelial transition (23). Homozygous $P A X 2$ null-mutant mice have no kidneys because the ureteric bud fails to branch from the mesonephric duct (22). Furthermore, the absence of mesonephric tubules suggests that PAX2 is required for mesenchymal/epithelial conversion in vivo, and Fallopian tubes are absent because PAX2 is expressed in Mullerian duct derivatives (24). $P A X 2$ mutations have also been found in humans, arising de novo or inherited in an autosomal dominant manner $(25,26)$. Heterozygous individuals with mutations of either the paired or octapeptide domains most likely have haploinsufficiency, a partial lack of functional protein. They suffer from optic nerve colobomas, vesicoureteric reflux, and "hypoplastic" kidneys, although histological analysis was not performed in the original report (25). Homozygous $P A X 2$ mutations have not been described in humans although known kindreds with kidney and Mullerian malformations superficially resemble the (female) mouse null-mutants $(22,27)$. PAX2 and PAX8 are overexpressed in Wilms tumor $(20,28$ 30), a malignant neoplasm containing tissues resembling the embryonic kidney, and also in renal cell carcinoma (31). Thus, in mice and humans, a deficiency of metanephric PAX2 protein is associated with growth failure while overexpression of the same protein is associated with cyst or tumor formation.

Human dysplastic kidneys are developmental aberrations which are responsible for many of the very young children who require dialysis and renal transplantation (32-35). They contain poorly differentiated metanephric cells in addition to meta- 
plastic elements $(32,34,35)$. We recently demonstrated that apoptosis was prominent in undifferentiated cells surrounding dysplastic tubules (36) perhaps explaining the tendency of some of these organs to involute (37). In contrast, apoptosis was less common in dysplastic epithelia (36) which are thought to be malformed branches of the ureteric bud (34). These tubules may form cysts large enough to distend the abdominal cavity (the multicystic dysplastic kidney) (34) and these kidneys may on occasion become malignant $(38,39)$. We now demonstrate that dysplastic tubules maintain a high rate of proliferation through the postnatal period, and that PAX2 protein, a potentially oncogenic transcription factor, is highly expressed in the nuclei of these epithelia. In contrast, both cell proliferation and PAX2 are downregulated during normal maturation.

\section{Methods}

Sources of normal and dysplastic organs. The modes of collection of specimens have been fully described (36). All abnormal kidneys met histological criteria for dysplasia based on the identification of immature tubules together with the presence of metaplastic cartilage (32, $34,35)$. In addition, undifferentiated and fibromuscular-like cells are seen around dysplastic epithelia and multicystic dysplastic kidneys

Table IA. Prenatal Samples

\begin{tabular}{|c|c|c|c|c|}
\hline $\begin{array}{l}\text { Gestational } \\
\text { age }\end{array}$ & Sex & $\begin{array}{c}\text { Renal } \\
\text { histology }\end{array}$ & $\begin{array}{c}\text { Termination/ } \\
\text { spontaneous } \\
\text { abortion }\end{array}$ & Other abnormalities \\
\hline \multicolumn{5}{|l|}{$w k$} \\
\hline 17 & $\mathrm{M}$ & Dysplasia & $\mathrm{T}$ & None \\
\hline 19 & $\mathrm{M}$ & Dysplasia & $\mathrm{T}$ & Hydrocephalus \\
\hline 19 & $\mathrm{M}$ & Dysplasia & $\mathrm{T}$ & Urethral obstruction \\
\hline 19 & $\mathrm{~F}$ & Dysplasia & $\mathrm{T}$ & None \\
\hline 20 & $\mathrm{M}$ & Dysplasia & $\mathrm{T}$ & Hypoplastic lungs \\
\hline 22 & M & Dysplasia & $\mathrm{T}$ & $\begin{array}{l}\text { Urethral obstruction, } \\
\text { atrial septal defect }\end{array}$ \\
\hline 22 & $\mathrm{M}$ & Dysplasia & $\mathrm{T}$ & None \\
\hline 24 & $\mathrm{~F}$ & Dysplasia & $\mathrm{T}$ & Hypoplastic lungs \\
\hline 32 & $\mathrm{~F}$ & Dysplasia & $\mathrm{S}$ & Hypoplastic lungs \\
\hline 34 & M & Dysplasia & $\mathrm{S}$ & Hypoplastic lungs \\
\hline 10 & $?$ & Normal & $\mathrm{T}$ & None \\
\hline 17 & $\mathrm{M}$ & Normal & $\mathrm{T}$ & Neural tube defect \\
\hline 19 & $\mathrm{~F}$ & Normal & $\mathrm{T}$ & Trisomy 21 \\
\hline 20 & M & Normal & $\mathrm{S}$ & Thalassemia trait \\
\hline 20 & $\mathrm{~F}$ & Normal & $\mathrm{S}$ & None \\
\hline 22 & $\mathrm{M}$ & Normal & $\mathrm{T}$ & Anorectal abnormality \\
\hline 25 & M & Normal & $\mathrm{S}$ & $\begin{array}{l}\text { Hyaline membrane } \\
\text { disease }\end{array}$ \\
\hline 25 & $\mathrm{~F}$ & Normal & $\mathrm{S}$ & $\begin{array}{l}\text { Hyaline membrane } \\
\text { disease }\end{array}$ \\
\hline 27 & $\mathrm{M}$ & Normal & $\mathrm{S}$ & Septicaemia \\
\hline 28 & $\mathrm{~F}$ & Normal & $\mathrm{S}$ & Growth retardation \\
\hline 32 & $\mathrm{~F}$ & Normal & $\mathrm{S}$ & Maternal pre-eclampsia \\
\hline 32 & M & Normal & $\mathrm{S}$ & $\begin{array}{l}\text { Pneumothorax, liver } \\
\text { tear }\end{array}$ \\
\hline
\end{tabular}

Chromosomes were normal in all cases assessed apart from the single case of Trisomy 21. Two of the dysplastic samples were associated with urethral obstruction. All abnormal organs were multicystic dysplastic kidneys. contain massive dilatated terminal segments of dysplastic tubules. In this study we have also included normal postnatal samples from children who died from Sudden Infant Death syndrome (SIDS). No renal or other pathology was detected in these samples at post mortem. The prenatal samples are documented in Table $I A$ and postnatal samples in Table $I B$; obstructed kidneys are indicated. Kidneys were fixed in $10 \%$ formalin and embedded in paraffin wax. Sections were cut at 4-6 $\mu \mathrm{m}$ and were counterstained with methyl green.

Immunohistochemistry. For PAX2 immunohistochemistry we used a rabbit polyclonal antibody raised against amino acids 188-385 in the carboxy-terminal domain of PAX2 (20): this sequence does not include the highly conserved paired domain which is located in the amino-terminal region of the full length PAX2 protein (18). Using cells transfected with $\mathrm{PAX} 2,5$, and 8 there is only appreciable reactivity to the former protein and, using deletion mutants of PAX2, this

Table IB. Postnatal Samples

\begin{tabular}{|c|c|c|c|c|}
\hline Age & Sex & $\begin{array}{l}\text { Renal } \\
\text { histology }\end{array}$ & $\begin{array}{l}\text { Additional } \\
\text { pathology }\end{array}$ & Obstruction \\
\hline \multicolumn{5}{|l|}{ mo } \\
\hline 4 & $\mathrm{~F}$ & Dysplasia & $\begin{array}{c}\text { Obstructed } \\
\text { ureterocoele }\end{array}$ & Yes \\
\hline 4 & M & Dysplasia & $\begin{array}{c}\text { Vesicoureteric junction } \\
\text { obstruction }\end{array}$ & Yes \\
\hline 5 & $\mathrm{~F}$ & Dysplasia & None & No \\
\hline 6 & M & Dysplasia & $\begin{array}{l}\text { Nonobstructed } \\
\text { megaureter }\end{array}$ & No \\
\hline 8 & $\mathrm{~F}$ & Dysplasia & $\begin{array}{l}\text { Duplex with dysplastic } \\
\text { obstructed upper pole }\end{array}$ & Yes \\
\hline 8 & M & Dysplasia & $\begin{array}{l}\text { Contralateral } \\
\text { hydronephrosis }\end{array}$ & No \\
\hline 9 & $\mathrm{~F}$ & Dysplasia & $\begin{array}{c}\text { Contralateral } \\
\text { vesicoureteric reflux }\end{array}$ & No \\
\hline 9 & $\mathrm{~F}$ & Dysplasia & None & No \\
\hline 14 & $\mathrm{~F}$ & Dysplasia & None & No \\
\hline 15 & M & Dysplasia & Ipsilateral reflux & No \\
\hline 19 & M & Dysplasia & None & No \\
\hline 24 & M & Dysplasia & None & No \\
\hline 3 & $\mathrm{~F}$ & Normal & SIDS & No \\
\hline 3 & $\mathrm{~F}$ & Normal & SIDS & No \\
\hline 3 & $\mathrm{~F}$ & Normal & SIDS & No \\
\hline 4 & $\mathrm{~F}$ & Normal & SIDS & No \\
\hline 4 & $\mathrm{~F}$ & Normal & SIDS & No \\
\hline 5 & $\mathrm{~F}$ & Normal & SIDS & No \\
\hline 5 & M & Normal & SIDS & No \\
\hline 6 & M & Normal & SIDS & No \\
\hline 7 & M & Normal & SIDS & No \\
\hline 14 & $\mathrm{~F}$ & Normal & SIDS & No \\
\hline 5 & $\mathrm{~F}$ & Normal & Wilms tumor & No \\
\hline 8 & M & Normal & Wilms tumor & No \\
\hline 28 & M & Normal & Wilms tumor & No \\
\hline 30 & M & Normal & Wilms tumor & No \\
\hline 38 & M & Normal & Wilms tumor & No \\
\hline 72 & $\mathrm{~F}$ & Normal & Wilms tumor & No \\
\hline
\end{tabular}

All abnormal kidneys were cystic dysplastic and three were attached to obstructed urinary systems. Sudden infant death syndrome (SIDS) patients died without any pathological cause being found at post mortem examination. These kidneys were histologically normal. In the Wilms tumor samples we examined the normal surrounding renal tissue. None of these children had WT1 mutations (36). 
Table II. Patterns of Gene Expression in Normal and Multicystic Dysplastic Kidneys

\begin{tabular}{lcccc}
\hline & PAX2 & PCNA & WT1 & BCL2 \\
\hline $\begin{array}{l}\text { Normal kidneys } \\
\text { Undifferentiated mesenchyme }\end{array}$ & - & rare + & rare + & - \\
$\quad \begin{array}{l}\text { Mesenchymal condensate } \\
\text { and vesicles }\end{array}$ & & & & \\
S-shaped bodies & ++ & ++ & + & ++ \\
Glomerular podocytes & ++ & ++ & + & + \\
Tips of ureteric bud (ampullae) & ++ & ++ & - & - \\
Immature collecting ducts & + & + & - & - \\
Mature collecting ducts & rare + & rare + & - & - \\
& & & & \\
Dysplastic kidneys & & & & \\
Dysplastic tubules & ++ & ++ & - & ++ \\
Cyst epithelia & ++ & ++ & - & + \\
Collarettes/undifferentiated cells & - & rare + & + & - \\
& & & & \\
\hline
\end{tabular}

- Indicates no staining, + to ++ indicate increasing intensity of staining present in the majority of cells in the designated population. 'Rare + ' indicates that $<10 \%$ of cells of these populations showed positive immunostaining.

antibody recognizes major epitopes between amino acids 270-338 (40). In homogenates of mouse metanephros the antibody recognizes a single major doublet (46-48 kD) on western blot (20). Our own unpublished observations show that this antibody recognizes similar bands on western blot of human fetal kidney (data available on request). For WT1 immunostaining we used a rabbit polyclonal IgG fraction raised against an epitope in the carboxy terminus of the human WT1 protein (C-19: Santa Cruz Biotechnology, Inc., CA). This antibody has been found by the manufacturer and also by other groups (41) to specifically recognize WT1 transcription factor/splicing factor protein on western blot. Our own unpublished observations also demonstrate that a protein doublet $(45-50 \mathrm{kD})$ is recognized by this antibody in western blot of reduced homogenates of human fetal, mature and dysplastic kidney (data available on request). Mouse monoclonal antibody to proliferating cell nuclear antigen (PCNA) ${ }^{1}$, a DNA-polymerase $\delta$-associated protein expressed at high levels during S phase (42), was purchased from Oncogene Science, Inc., (Cambridge, MA) (PCNA Ab-1). Monoclonal mouse antibody to human BCL2 was purchased from DAKO (clone 124; DAKO A/S, Glostrup, Denmark). All other chemicals were supplied by Sigma (Poole, Dorset, UK) unless otherwise stated.

Immunohistochemistry was performed using conventional techniques as follows. Sections were dewaxed through Histo-Clear (National Diagnostics, Atlanta, GA) twice for $10 \mathrm{~min}$, followed by rehydration through $100 \%$ alcohol (Hayman Ltd., Witham, Essex, UK) twice for $5 \mathrm{~min}$ and then stepwise through $95,90,75,50$, and $30 \%$ alcohol for 3 min each. After washing in phosphate buffered saline (PBS, $\mathrm{pH}$ 7.4) for $5 \mathrm{~min}$ and running tap water for ten minutes they were immersed in Citric acid buffer (2.1 g/l, pH 6.0) and boiled in a microwave for 8-15 min. They were then allowed to cool, rewashed in tap water and PBS, then incubated in 3\% hydrogen peroxide for 15 min to quench endogenous peroxidase activity. After two further washes in PBS, non specific antibody binding was blocked with $10 \%$ fetal calf serum/PBS and the primary antibody was then applied for one hour at $37^{\circ} \mathrm{C}$. WT1, PCNA, and BCL2 antibodies were used at a

1. Abbreviation used in this paper: PCNA, proliferating cell nuclear antigen.
1 in 50 dilution and the PAX2 antibody at a concentration of $10 \mathrm{mg} /$ liter. Primary antibodies were detected using a streptavidin biotin peroxidase system (Dako, ABC Kit) followed by diamino benzidine (DAB). They were then counterstained with $0.5 \%$ methyl green for $10 \mathrm{~min}$, washed three times with water and butanol, once in histoclear for $10 \mathrm{~min}$, and mounted in DPX (BDH, Poole, UK). Specimens were examined and photographed on a Zeiss Axiophot microscope (Carl Zeiss, 7082 Oberkochen, Germany).

\section{Results}

Consistent patterns of gene expression were noted in each group. Results are summarized in Table II, are described below, and are illustrated in Figs. 1-4.

$P A X 2$ in normal human nephrogenesis. The human metanephros can be identified at 5 wk gestation and consists of a ureteric bud and renal mesenchyme. The first glomeruli form at $9 \mathrm{wk}$ and a nephrogenic zone is maintained to $34 \mathrm{wk}$ (34). Renal mesenchymal cells do not express PAX2 protein (Fig. 1, $A, C-E$ and Fig. 2, A). As this lineage differentiates PAX2 was expressed during mesenchymal to epithelial transition, first in mesenchymal condensates and then in vesicles and commashaped bodies (Fig. 1, $A, C$ and $D$, and Fig. 2, A). As expected for a transcription factor, immunoreactivity was intense in nuclei, although some cytoplasmic staining was also noted (Fig. 1, $E$ and $H$ ). In the next stage of nephron maturation, the S-shaped bodies, PAX2 was detected in all elements apart from precursors of glomerular visceral epithelia (Fig. 1, E). In the capillary loop stage of glomerulogenesis faint PAX2 immunoreactivity was present in parietal epithelia and in adjoining proximal tubules (Fig. $1 G-H)$. PAX2 protein was not detected in mature glomeruli (Fig. 1, I). In the ureteric bud lineage, intense PAX2 immunoreactivity was detected in branching ampullae, each of which is flanked by mesenchymal condensates (Fig. 1, $A, C$ and $D$ and Fig. 2, $A$ ). Nuclei in fetal cortical and medullary collecting ducts showed weaker but consistent immunostaining (Fig. 1, $F$ and $G$ ). Mature collecting duct cells generally had no significant staining above control sections in which the anti-PAX2 antibody had been omitted, although occasional $(<10 \%)$ nuclei showed faint immunoreactivity (Fig. 1, $I$ and Fig. 2, $C$ ).

$P A X 2$ in human multicystic dysplastic kidneys. Multicystic dysplastic kidneys contain dysplastic tubules which are thought to be malformations of ureteric bud branches (34). Studies by Potter revealed that these tubules were connected to cysts (34). The tubules are immediately surrounded by fibromuscular-like cells and, further from the tubule, there are looser-packed undifferentiated cells (Fig. 2, $E$ and $F$, Fig. 3, $C$ and $D$ and Fig. 4, $C$ and $D$ ). All nuclei of epithelia lining the dysplastic tubules stained intensely with antiserum to PAX2 and the flattened epithelial cells lining cysts were also positive (Fig. 2, $E$ and $G$ ). In contrast the poorly differentiated cells surrounding the tubules did not express PAX2 (Fig. 2, E and $G)$. Strikingly, the same pattern of PAX2 expression was detected in both prenatal and postnatal multicystic dysplastic kidneys. Thus, PAX2 expression is not downregulated with time in these organs.

PCNA in normal and abnormal human nephrogenesis. PCNA is associated with DNA replication machinery and is strongly expressed in S phase (42). When identified in cell nuclei, it can be used as a surrogate marker of proliferation. In normal human nephrogenesis, nuclei with PCNA immunore- 

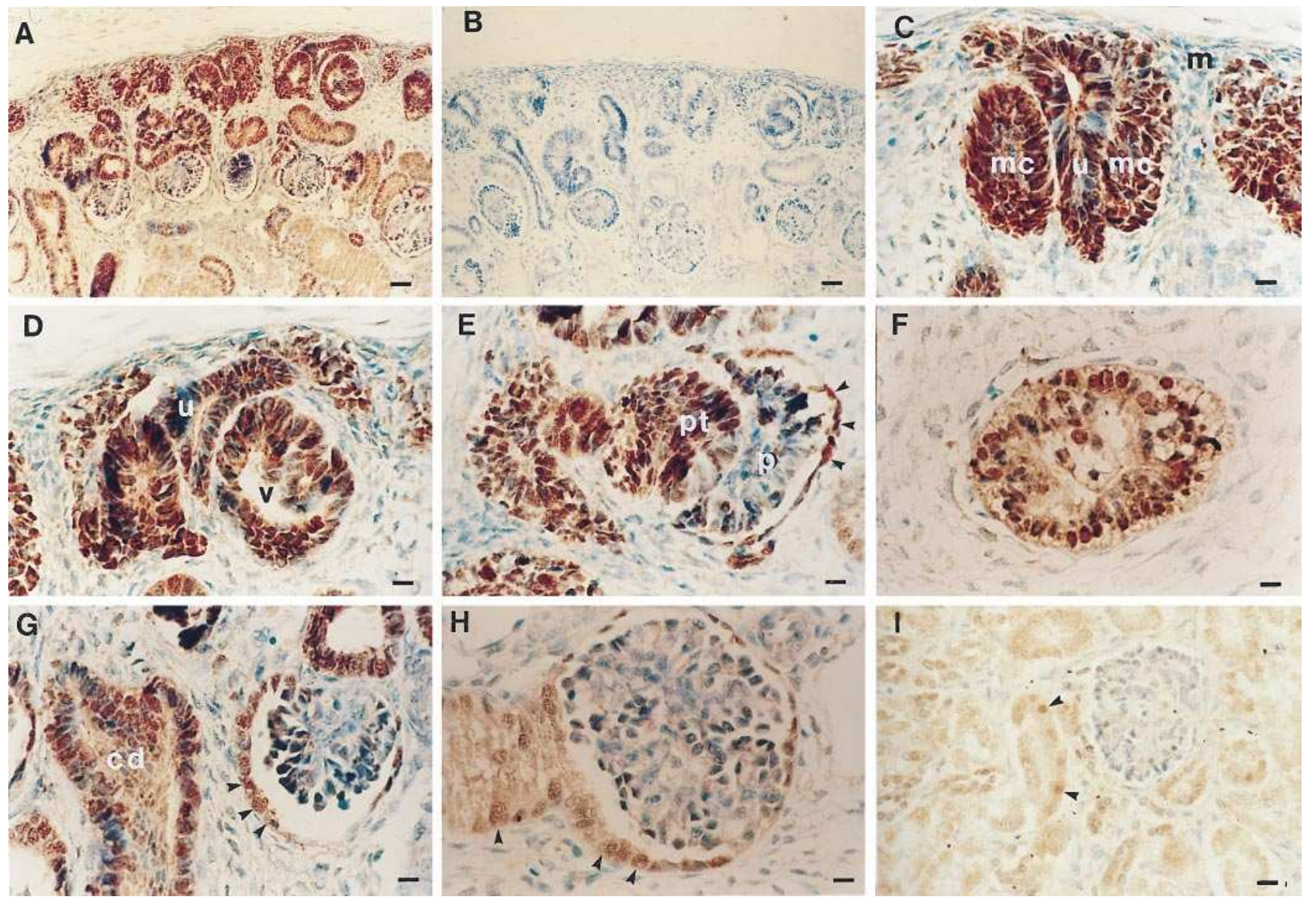

Figure 1. PAX2 immunostaining during normal human nephrogenesis. All sections are from a normal human 10-wk gestation kidney apart from $(I)$ which is a 6-mo normal postnatal kidney. $(A)$ Note PAX2 (brown color) in the nephrogenic zone with decreasing levels towards the maturing center. Bar, $12 \mu \mathrm{m}$. (B) Same field as $A$ but no first antibody. Bar, $12 \mu \mathrm{m}$. (C) Intense PAX2 expression in a ureteric bud branch tip (u) and in mesenchymal condensates $(m c)$. Note that the undifferentiated mesenchyme $(m)$ has no PAX2 staining. Bar, $3 \mu \mathrm{m}$. $(D)$ A little later in development, a vesicle $(v)$ has formed. Bar, $3 \mu \mathrm{m}$. (E) PAX2 expression in a primitive proximal tubule $(p t)$ and in parietal glomerular epithelia (arrowheads). Note PAX2 downregulation in maturing podocytes $(p)$. Bar, $3 \mu \mathrm{m}$. $(F)$ PAX2 in a fetal medullary collecting duct. Bar, $3 \mu \mathrm{m}$. $(G)$ On the left a maturing cortical collecting duct has less intense staining: on the right, a fetal glomerulus shows only faint PAX2 staining in Bowman's capsule (arrowheads). Bar, $3 \mu \mathrm{m}$. (H) Capillary loops are noted in this fetal glomerulus with faint PAX2 staining in visceral epithelia and proximal tubule (arrowheads). Bar, $3 \mu \mathrm{m}$. (I) In the postnatal kidney PAX2 is downregulated but rare nuclei are faintly positive (arrowheads). Bar, $6 \mu \mathrm{m}$.

activity were scarce within the undifferentiated mesenchyme but the protein is highly expressed during the mesenchymal to epithelial transition and also in the ampullary tips of the branches of the ureteric bud (Fig. 2, B). In postnatal normal kidneys PCNA positive cells were still detected in all parts of the nephron (Fig. 2, D) but they were extremely scarce $(<1 \%$ of total nuclei). Within human kidney malformations, 20$100 \%$ of epithelial nuclei in dysplastic tubules were positive for PCNA (Fig. 2 F). Furthermore, staining was positive in a similar proportion of cells in cystic epithelia (Fig. 2, $H$ ). Multicystic kidneys harvested pre- and postnatally showed similar patterns. Thus, PAX2 expression is associated with proliferation in normal fetal kidneys and in dysplastic tubules and cysts. Additionally, some nuclei were positive for PCNA in undifferentiated tissue around dysplastic tubules (Fig. 2, F).

BCL2 in normal and abnormal human nephrogenesis. BCL2 protects developing cells from programmed cell death $(43,44)$. In normal fetal kidneys immunoreactivity was first detected in mesenchymal condensates (Fig. 3, $A$ and $B$ ), a stage at which both PCNA and PAX2 expression were present (Fig. 2, $A$ and $B$ ). Thereafter, BCL2 was downregulated (Fig. 3, $A$ and $B$ ) in the developing nephron apart from in descending loops of Henle (data not shown). We did not detect BCL2 immunoreactivity in ureteric bud derivatives such as ampullae and collecting ducts (Fig. 3, $A$ and $B$ ). In dysplastic kidneys, BCL2 protein was consistently expressed within the cytoplasm of dysplastic tubule epithelia but was absent from surrounding collarettes and other poorly differentiated cells (Fig. 3, C and $D)$. This is an ectopic pattern since dysplastic tubules are derived from the ureteric bud (34), but this lineage does not normally express BCL2. Moreover, we found that BCL2 expression was not downregulated postnatally in dysplastic tubules.

WT1 in normal and abnormal human nephrogenesis. WT1 is essential for early nephrogenesis $(41,45,46)$. In normal fetal kidneys WT1 was faintly expressed in nuclei of condensates and vesicles (Fig. 4, $A$ ). The intensity of staining increased in the proximal limbs of S-shaped bodies, with the highest levels in immature glomerular podocytes (Fig. 4, A), a 

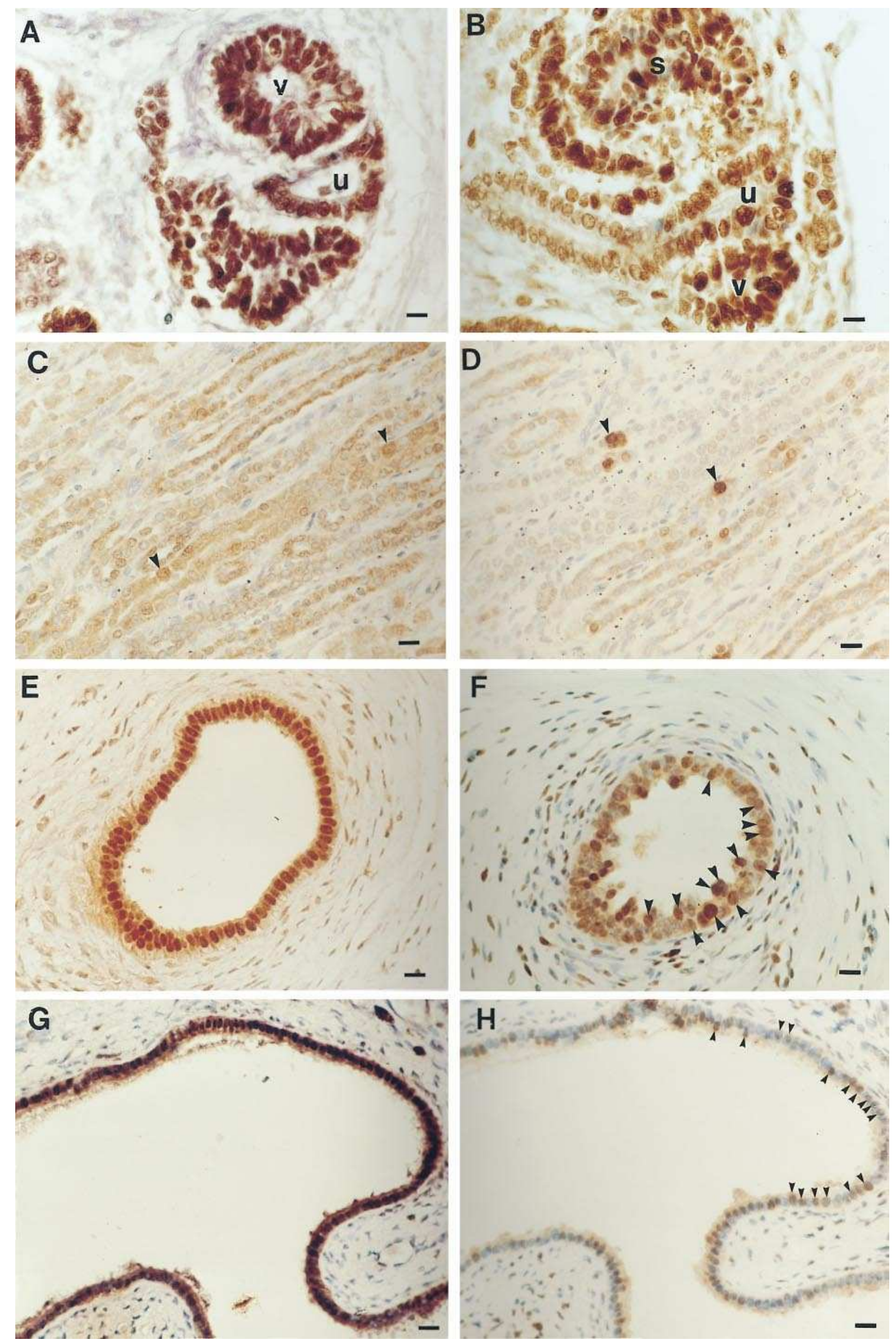

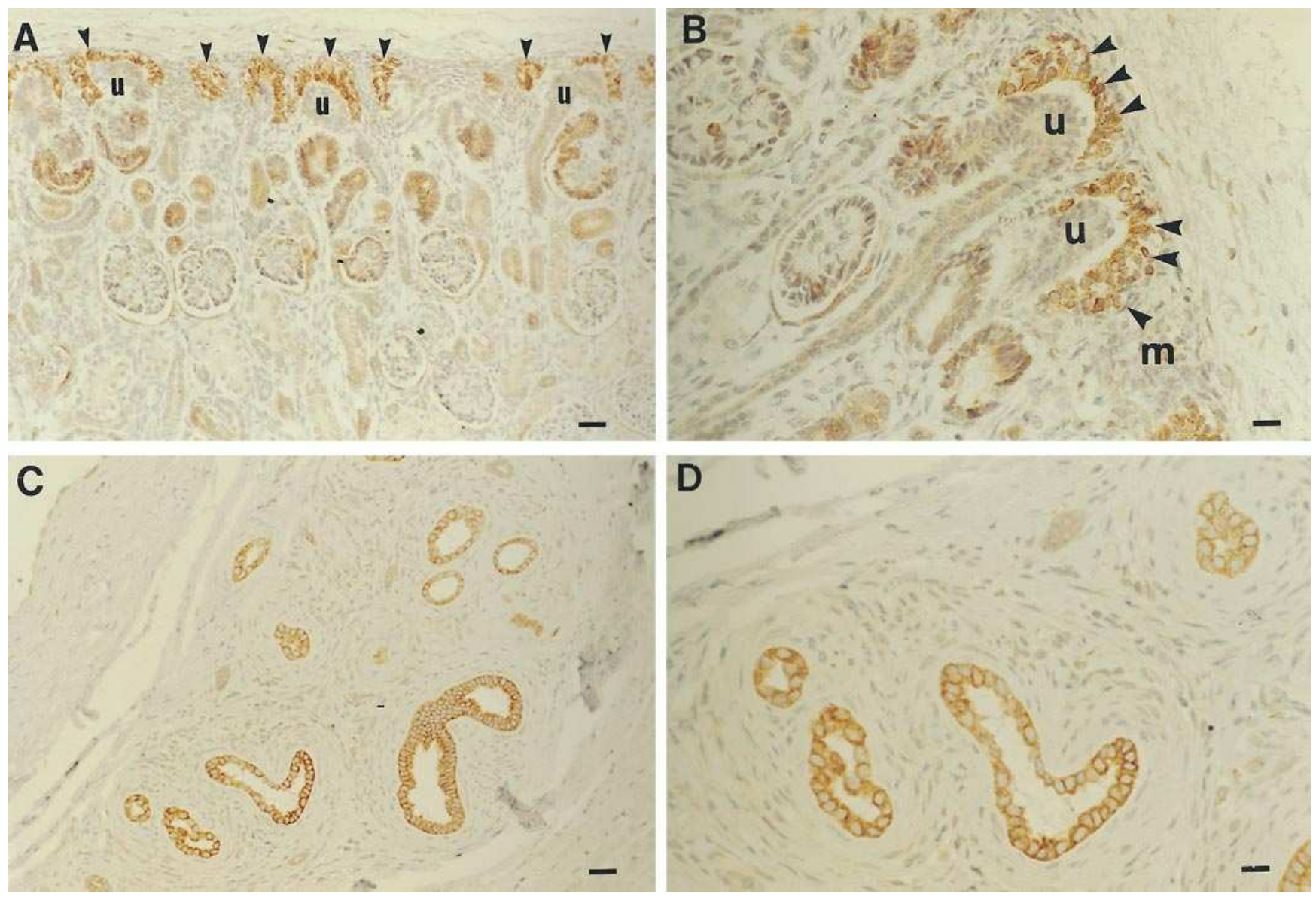

Figure 3. BCL2 immunostaining in dysplastic human kidneys. (A) 10-wk normal human fetal kidney. BCL2 is prominent in mesenchymal condensates (arrowheads). Bar, $12 \mu \mathrm{m}$. (B) High power of normal nephrogenic zone. Note intense BCL2 staining in mesenchymal condensates (arrowheads) but the ureteric bud branches $(u)$ are negative. Bar, $4 \mu \mathrm{m}$. (C) Low power field of a dysplastic kidney. Numerous dysplastic tubules stain intensely for BCL2 protein while the surrounding collarettes and undifferentiated cells are negative. Bar, $12 \mu \mathrm{m}$. $(D)$ Higher power of $(C)$. Bar, $6 \mu \mathrm{m}$.

pattern which persisted postnatally (data not shown). WT1 protein was not detected in derivatives of the ureteric bud. In dysplastic kidneys, WT1 nuclear protein was absent in dysplastic epithelia but was detected in $10-80 \%$ of fibromuscular and undifferentiated cells around malformed tubules (Fig. 4, C). The intensity of staining in these cells was similar to that observed in the early stages of nephron formation but less than the nuclear staining in glomerular podocytes (Fig. 4, A).

Metaplastic cartilage was negative for PAX2, BCL2, and WT1. Gene expression patterns were similar in dysplastic kidneys with either patent or obstructed lower urinary tracts (see Table I, $A$ and $B$ for patient details).

\section{Discussion}

PAX2 and normal human nephrogenesis. This is the first study to document the detailed expression of PAX2 protein in hu- man nephrogenesis. We found that PAX2 is regulated both in developmental space and time in cells undergoing critical morphogenetic events including both mesenchymal/epithelial transition and branching morphogenesis. Similar nephrogenic expression domains have been reported for mouse PAX2 mRNA (18) and protein (20) and human mRNA (28). In common with Hanai and co-workers (47), who used PCNA staining in mice kidneys, we found a high proliferation index in the nephrogenic cortex of fetal kidneys but that proliferation was markedly downregulated postnatally. Our data show that, in both mesenchymal and ureteric bud derivatives, the most intense expression of PAX2 protein occurred in populations of epithelial precursors with the highest proliferation index. In the postnatal period it was rare to identify nuclei which were positive for either PAX2 or PCNA.

Normal relationship of PAX2 expression to WT1. Mundlos and colleagues detected low levels of WT1 protein in human renal

Figure 2. PAX2 and PCNA immunostaining in dysplastic kidneys. $A, C, E$, and $G$ are stained for PAX2. $B, D, F$, and $H$ are stained for PCNA. $A$ and $B$ show a normal nephrogenic zone. PAX2 and proliferation are localized to bud branch tips $(u)$ and flanking primitive nephrons; $(v)$ is a vesicle stage and $(s)$ is an S-shaped body. Bars, $2 \mu \mathrm{m}$. $C$ and $D$ show medulla of a normal postnatal kidney with rare PAX2 positive collecting ducts (arrowheads in $C$ ). Cell proliferation is also rare: arrowheads in $(D)$. Bars, $6 \mu \mathrm{m}$. $E-H$ are from a postnatal dysplastic kidney. Note PAX2 in dysplastic tubules $(E)$ and cystic epithelia $(G)$. Surrounding undifferentiated cells are negative. Many epithelial cell nuclei in these kidney malformations also stain for PCNA: (arrowheads in $F$ and $H$ ). Bars, $6 \mu \mathrm{m}$. 


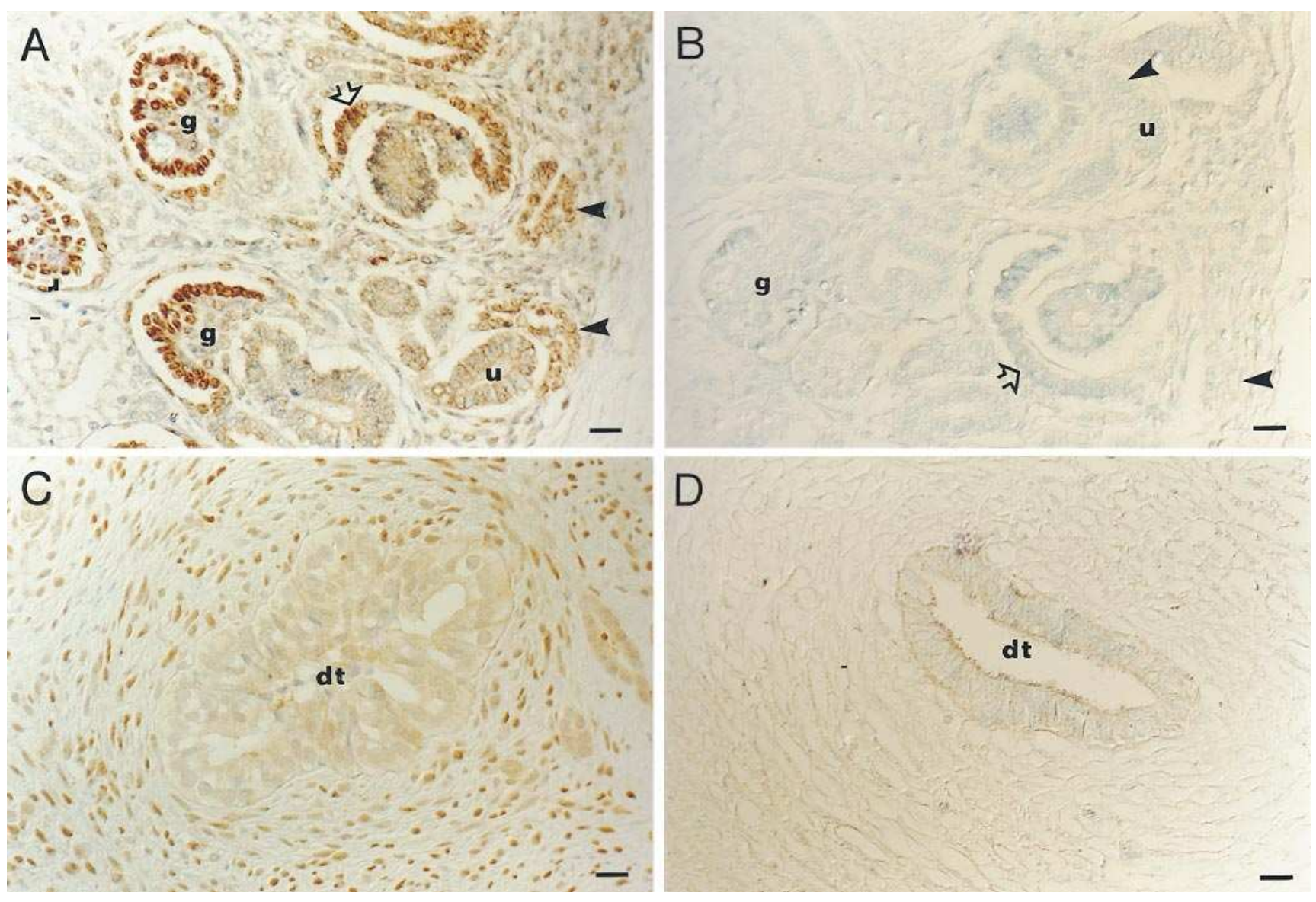

Figure 4. WT1 immunostaining in dysplastic human kidneys. (A) Normal human fetal kidney shows a gradient of WT1 immunoreactivity from nephrogenic cortex (right) to maturing nephrons (left). Note that cells in condensates and vesicles (arrowheads) are weakly positive for WT1 immunostaining. Expression increases in the mesenchymal to epithelial transition with high WT1 levels in the proximal limb of S-shaped bodies (open arrowheads) and the podocytes of fetal glomeruli $(g)$. A ureteric bud branch tip $(u)$ is negative. (B) Similar field to $A$ but first antibody omitted shows no staining. $(C)$ In human kidney malformations dysplastic tubules $(d t)$ show no significant staining with the WT1 antibody. In contrast, nuclei of fibromuscular and undifferentiated cells located around the tubule are positive for WT1. $(D)$ Similar field to $C$ but first antibody omitted shows minimal background staining in the cytoplasm of the dysplastic tubule. Bars, $10 \mu \mathrm{m}$.

mesenchyme but not in vesicles with an antibody raised against the first alternative spice site in WT1 (48). Another group found little protein expression in condensing renal mesenchyme of mice with an antibody raised against aa 1-179 of WT1 (2). We found faint but positive WT1 staining in renal condensates and vesicles using an antibody raised against the carboxy terminus. In accord with previous studies $(2,48)$, we observed that the level of WT1 increased in S-shaped bodies and podocytes. Thus our study identified WT1 protein at a slightly earlier stage during the mesenchymal to epithelial transition as compared with previous reports. We suggest that this difference may be attributed to a more sensitive staining technique or to the fact that antibodies were raised to different regions of WT1 and may thus have the capacity to recognize different isoforms. Furthermore, the fact that homozygous WT1 null mutant mice have absent kidneys due to lack of induction and subsequent apoptosis of renal mesenchyme (46) would appear to suggest that low, but biologically important, levels of WT1 protein are indeed expressed even before the condensate or vesicle stages. There is biochemical evidence that WT1 can repress transcription of PAX2 (2), consistent with the general inverse relationship between PAX2 and WT1 noted during glomerular podocyte maturation in our study. Of note, the normal downregulation of PAX2 in maturing collecting ducts was not associated with WT1 expression, suggesting that other molecules switch-off PAX2 in this lineage.

Normal relationship of $P A X 2$ expression to BCL2. Our observations of BCL2 expression in normal human nephrogenesis accord with a recent study (49). $B c l 2$ null mutant mice are born with hypoplastic kidneys and metanephric growth in organ culture is restricted due to apoptosis $(44,50)$. Thus BCL2 is required to prevent death of proliferating nephron precursors. The fact that PAX2, BCL2, and PCNA proteins are highly expressed together in the mesenchymal condensate suggests that PAX2 and BCL2 are important molecules for cell proliferation and survival in this first morphogenetic step in nephron formation. Although we found that PAX2 expression correlated with proliferation in ureteric bud branches, BCL2 was not expressed in these normal ampullae, and our previous observations suggest that these structures are not sites of marked apoptosis (36). It is possible that these cells express other anti-death molecules (e.g., $\mathrm{BCL}_{\mathrm{XL}}$ ) or have lower levels of apoptosis-inducing molecules (e.g., BAX) (51).

Cell lineages and biology of multicystic dysplastic kidneys. Classical studies by Edith Potter described the anatomy of dys- 
plastic kidneys (34). This and other work (52) suggests that dysplastic tubules are malformed branches of the ureteric bud while dysplastic cysts correspond to distended ampullae (34). The cells surrounding these epithelia are undifferentiated "mesenchymal" or "stromal" cells as well as metaplastic cells with characteristic fibromuscular morphology (the "collarettes" immediately surrounding dysplastic tubules) and cartilage (32, 34-36). These cells probably originate as renal mesenchymal or intermediate mesoderm cells which either fail to develop or differentiate along inappropriate pathways. Another possibility is that some of these cells derive from the ureteric bud since one recent study demonstrated a contribution of the bud to stroma in metanephric organ culture (53).

Very little is known about the cell biology of human multicystic dysplastic kidneys. We recently demonstrated that the incidence of apoptosis was increased in cells surrounding dysplastic epithelia but that programmed cell death was rare in the abnormal epithelia themselves (36). We suggested that the tendency for some of these organs to regress (37) and the failure to form mature nephrons might be explained by increased programmed cell death.

Aberrant PAX2 and BCL2 expression correspond with death and proliferation in renal dysplasia. We can now associate defined patterns of gene expression with hyperproliferation in dysplastic epithelia and with cell death in surrounding cells (36). Many of the cells around dysplastic tubules express WT1 protein with an intensity comparable to that found in the normal primitive nephron and thus appear to have been induced. If this is so, why do they fail to differentiate and why is apoptosis common? (36) We suggest that the answer lies firstly in the absence of PAX2 expression, causing failure to undergo mesenchymal/ transition, and secondly in a lack of BCL2, resulting in a failure of precursor survival. Using similar reasoning we speculate that cyst formation in dysplastic kidneys is caused by persistent expression of PAX2, which would provide a continuous proliferation signal, and ectopic BCL2 expression which would prevent immature epithelia from dying. Moreover, the persistent postnatal expression of PAX2 could contribute to the genesis of the tumors which have been reported in dysplastic kidneys $(38,39)$.

Conclusions. We propose that cyst formation in human dysplastic kidney malformations can be understood in terms of aberrant temporal and spatial expression of master genes which are tightly developmentally-regulated during the normal program of human nephrogenesis. In the future it will be interesting to document the expression in these dysplastic organs of other molecules known to be associated with development of ureteric bud derivatives. These include met $(54,55)$, ros $(56)$, ret (57), epidermal growth factor receptor (58), low affinity nerve growth factor receptor (59) and L-myc (60). Further studies are now necessary to determine whether the aberrant patterns of gene expression we have documented have their origin in either mutations of genes expressed in nephrogenesis or in nongenetic factors such as teratogens: both types of pathogenetic mechanism have been implicated in human and animal kidney malformations (61). Finally, although urinary tract obstruction has been implicated as causing renal dysplasia, we found no difference in gene expression between obstructed and nonobstructed organs.

\section{Acknowledgments}

We would like to thank Philip Ransley, Patrick Duffy, Pierre Mouriquand, Jeeta Dhillon, Fergal Quinn, and Helen Pardoe for their help in collecting the surgical specimens, and to Sue Howard and Dianne Rampling for technical help.

P.J.D. Winyard is supported by a Training Fellowship from Action Research. A.S. Woolf is an N.K.R.F. Senior Fellow.

\section{References}

1. Gilbert, S.F. 1991. Developmental Biology, Third Edition. Sinauer Associates, Inc. Sunderland, Massachusetts. 376-457.

2. Ryan, G., V. Steele-Perkins, J.F. Morris, F.J. Rauscher III, and G.R. Dressler. 1995. Repression of Pax-2 by WT1 during normal kidney development. Development (Camb.). 121:867-875.

3. Song, D.-L., G. Chalepakis, P. Gruss, and A.L. Joyner. 1996. Two Paxbinding sites are required for early embryonic brain expression of an Engrailed-2 transgene. Development (Camb.). 122:627-635.

4. Gruss, P., and C. Walther. 1992. Pax in development. Cell. 69:719-722.

5. Stapleton, P., A. Weith, P. Urbanek, Z. Kozmik, and M. Busslinger. 1993. Chromosomal localisation of seven Pax genes and cloning of a novel family member, Pax9. Nat. Genet. 3:292-298.

6. Halder, G., P. Callaerts, W.J. Gehring. 1995. Induction of ectopic eyes by targeted expression of the eyeless gene in Drosophila. Science (Wash. DC). 267: 1788-1792.

7. Hyatt, G.A., E.A. Schmitt, N. Marsh-Armstrong, P. McCaffery, U.C Drager, and J.E. Dowling. 1996. Retinoic acid establishes ventral retinal characteristics. Development (Camb.). 122:195-204.

8. Max, E.E., Y. Wakatsuki, M.F. Neurath, and W. Strober. 1995. The role of BSAP in immunoglobulin isotype switching and B-cell proliferation. Curr. Topics Microbiol. Immunol. 194:449-458.

9. Keller, S.A., J.M. Jones, A. Boyle, L.L. Barrow, P.D. Killen, D.G. Green, N.V. Kapousta, P.F. Hitchcock, R.T. Swank, and M.H. Meisler. 1994. Kidney and retinal defects $(K r d)$, a transgene-induced mutation with a deletion of mouse chromosome 19 that includes the Pax2 locus. Genomics. 23:309-320.

10. Matsuo, T., N. Osumi-Yamashita, S. Noji, H. Ohuchi, E. Koyama, F. Myokai, N. Matsuo, S. Taniguchi, H. Doi, S. Iseki, et al. 1993. A mutation in the Pax-6 gene in rat small eye is associated with impaired migration of midbrain crest cells. Nat. Genet. 3:299-304.

11. Goulding, M.D., G. Chalapakis, U. Deutsch, J.R. Erselius, and P. Gruss. 1991. Pax-3, a novel murine DNA binding protein expressed during early neurogenesis. EMBO (Eur. Mol. Biol. Organ.) J. 10:1135-1147.

12. Wallin, J., H. Eibel, A. Neubuser, J. Wilting, H. Koseki, and R. Balling. 1996. Pax1 is expressed during the development of the thymus epithelium and is required for normal T-cell maturation. Development (Camb.). 122:23-30.

13. Maulbecker, C.C., and P. Gruss. 1993. The oncogenic potential of Pax genes. EMBO (Eur. Mol. Biol. Organ.) J. 12:2361-2367.

14. Read, A.P. 1995. Pax genes - Paired feet in three camps. Nat. Genet. 5: 333-334.

15. Tassabehji, M., A.P. Read, V. E. Newton, M. Patton, P. Gruss, R. Harris, and T. Strachan. 1993. Mutations in the Pax 3 gene causing Waardenburg syndrome type 1 and 2. Nat. Genet. 3:26-30.

16. Hanson, I.M., A. Seawright, K. Hardman, S. Hodgson, D. Zaletayev, G Fekete, and V. van Heyningen. 1993. Pax 6 mutations in aniridia. Hum. Mol. Genet. 2:915-920.

17. Barr, F.G., N. Galili, J. Holick, J.A. Biegel, G. Rovera, and B.A. Emanuel. 1993. Rearrangement of the Pax3 paired-box gene in the paediatric solid tumour alveolar rhabdomyosarcoma. Nat. Genet. 3:113-117.

18. Dressler, G.R., U. Deutsch, K. Chowdhury, H.O. Nornes, P. Gruss. 1990. Pax2, a new murine paired-box-containing gene and its expression in the developing excretory system. Development (Camb.). 109:787-795.

19. Plachov, D., K. Chowdhury, C. Walther, D. Simon, J.-L. Guenet, and P. Gruss. 1990. Pax8, a murine paired box gene expressed in the developing excretory system and thyroid gland. Development (Camb.). 110:643-651.

20. Dressler, G.R., and E.C. Douglas. 1992. Pax-2 is a DNA-binding protein expressed in embryonic kidney and Wilms tumor. Proc. Natl. Acad. Sci. USA. 89:1179-1183.

21. Dressler, G.R., J.E. Wilkinson, U.W. Rothenpieler, L.T. Patterson, L. Williams-Simons, and H. Westphal. 1993. Deregulation of Pax-2 expression in transgenic mice generates severe kidney abnormalities. Nature (Lond.). 362:6567.

22. Torres, M., E. Gomex-Pardo, G.R. Dressler, and P. Gruss. 1995. Pax-2 controls multiple steps of urogenital development. Development (Camb.). 121: 4057-4065.

23. Rothenpieler, U.W., and G.R. Dressler. 1993. Pax-2 is required for mesenchyme-to-epithelium conversion during kidney development. Development (Camb.). 119:711-720.

24. Fickenscher, H.R., G. Chalepakis, and P. Gruss. 1993. Murine Pax-2 protein is a sequence-specific trans-activator with expression in the genital system. DNA Cell Biol. 12:381-391.

25. Sanyanusin, P., L.A. Schimmentl, L.A. McNoe, T.A. Ward, M.E.M. Pierpoint, M.J. Sullivan, W.B. Dobyns, and M.R. Eccles. 1995. Mutations of the PAX2 gene in a family with optic nerve colobomas, renal anomalies and vesi- 
coureteral reflux. Nat. Genet. 9:358-364.

26. Sanyanusin, P., L.A. McNoe, M.J. Sullivan, R.G. Weaver, and M.R. Eccles. 1995. Mutation of $P A X 2$ in two siblings with renal-coloboma syndrome. Hum. Mol. Genet. 4:2183-2184.

27. Battin, J., D. Lacombe, and J.J. Leng. 1993. Familial occurrence of hereditary renal adysplasia with Mullerian anomalies. Clin. Genet. 43:23-24.

28. Eccles, M.R., L.J. Wallis, A.E. Fidler, N.K. Spurr, P.J. Goodfellow, and A.E. Reeve. 1992. Expression of the $P A X 2$ gene in human fetal kidney and Wilm's tumor. Cell Growth \& Differ. 3:279-289.

29. Poleev, A., F. Wendler, H. Fickensher, M.S. Zannini, K. Yaginuma, C. Abbott, and D. Plachov. 1995. Distinct functional properties of three human paired-box-protein, PAX 8, isoforms generated by alternative splicing in thyroid, kidney and Wilm's tumors. Eur. J. Biochem. 228:899-911.

30. Sharma, P.M., M. Bowman, B.F. Yu, and S. Sukumar. 1994. A rodent model for Wilm's tumors: embryonal kidney neoplasms induced by N-notrosoN'-methylurea. Proc. Natl. Acad. Sci. USA. 91:9931-9935.

31. Gnarra, J.R., and G.R. Dressler. 1995. Expression of Pax-2 in human renal cell carcinoma and growth inhibition by antisense oligonucleotides. Cancer Res. 55:4092-4098.

32. Bernstein, J. 1992. Renal hypoplasia and dysplasia. In Pediatric Kidney Disease. C.M. Edelman, Jr., editor. Little, Brown. Boston, MA. 1121-1138.

33. Ehrich, J.H.H., G. Rizzoni, F.P. Brunner, W. Fassbinder, W. Geerlings, N.P. Mallick, A.E.G. Raine, N.H. Selwood, and G. Tufveson. 1992. Renal replacement therapy for end-stage renal failure before 2 years of age. Nephrol. Dial. Transplant. 7:1171-1177.

34. Potter, E.L. 1972. Normal and Abnormal Development of the Kidney. Year Book Medical Publishers Inc., Chicago. 1-350.

35. Risdon, R.A. 1971. Renal dysplasia. Part 1. A clinico-pathological study of 76 cases. J. Clin. Path. 24:57-71.

36. Winyard, P.J.D., J. Nauta, D.S. Lirenman, P. Hardman, V.R. Sams, R.A. Risdon, and A.S. Woolf. 1996. Deregulation of cell survival in cystic and dysplastic renal development. Kidney Int. 49:135-146.

37. Dungan, J.S., M.T. Fernandez, P.L. Abbitt, S. Thiagarajah, S.S. Howards, and W.A. Hogge. 1990. Multicystic dysplastic kidney: natural history of prenatally detected cases. Prenatal Diag. 10:175-182.

38. Barrett, D.M., and R.E. Wineland. 1980. Renal cell carcinoma in multicystic dysplastic kidney. Urology. 15:152-154.

39. Cromie, W.J., M.S. Engelstein, and J.W. Dickett. 1980. Nodular renal blastema, renal blastema and duplicated collecting systems. J. Urol. 123:100102.

40. Phelps, D.A., and G.R. Dressler. 1996. Indentification of novel Pax-2 binding sites by chromatin precipitation. J. Biol. Chem. 271: 7978-7985.

41. Larsson, S.H., J.-P. Charlieu, K. Miyagawa, D. Engelkamp, M. Rassoulzadegan, A. Ross, F. Cuzin, V. van Heyningen, and N. Hastie. 1995. Subnuclear localisation of WT1 in splicing of transcription factor domains is regulated by alternative splicing. Cell. 81:391-401.

42. Bravo, R., R. Frank, P.A. Blundell, and H. MacDonald-Bravo. 1987. Cyclin/PCNA is the auxillary protein of DNA polymerase-delta. Nature (Lond.). 326:515-517.

43. Hockenberry, D.G., C. Nunez, C. Milliman, R.D. Schreiber, and S.J. Korsmeyer. 1990. Bcl-2 is an inner mitochondrial membrane protein that blocks programmed cell death. Nature (Lond.). 348:334-336.

44. Veis, D.J., C.M. Sorenson, J.R. Shutter, and S.J. Korsmeyer. 1994. Bcl-2-deficient mice demonstrate fulminant lymphoid apoptosis, polycystic kidneys and hypopigmented hair. Cell. 75:229-240.
45. Pritchard-Jones, K., S. Flemming, D. Davidson, W.A. Bickmore, D. Porteus, C. Gosden, J. Bard, A. Buckler, J. Pelletier, D. Housman, V. van Heyningen, and N. Hastie. 1990. The candidate Wilm's tumor gene is involved in genitourinary development. Nature (Lond.). 346:194-197.

46. Kreidberg, J.A., H. Sariola, J.M. Loring, M. Maeda, J. Pelletier, D. Housman, and R. Jaenisch. 1993. WT-1 is required for early kidney development. Cell. 74:679-691.

47. Hanai, T., N. Usuda, T. Morita, T. Shimizu, and T. Nagata. 1993. Proliferative activity in the kidneys of aging mice evaluated by PCNA/cyclin immunohistochemistry. Cell Mol. Biol. 39:181-191.

48. Mundlos, S., J. Pelletier, A. Darveau, M. Bachmann, A. Winterpacht, and B. Zabel. 1993. Nuclear localisation of the protein encoded by the Wilm's tumor gene WT1 in embryonic and adult tissues. Development (Camb.). 119: 1329-1343.

49. Veis, D.J., and S.J. Korsmeyer. 1994. Bcl-2 protein expression during murine development. Am J Pathol. 145:61-73.

50. Sorenson, C.M., S.A. Rogers, S.J. Korsmeyer, and M.R. Hammerman. 1995. Fulminant metanephric apoptosis and abnormal kidney development in bcl-2 deficient mice. Am. J. Physiol. 268:F73-F81.

51. Oltvai, Z.N., C.L. Milliman, and S.J. Korsmeyer. 1993. Bcl-2 heterodimerises in vivo with a conserved homologue, bax, that accelerates programmed cell death. Cell. 74:609-619.

52. Maizel, M., and S.B. Simpson. 1983. Primitive ducts of renal dysplasia induced by culturing ureteral buds denuded of condensed renal mesenchyme. Science (Wash. DC). 219:509-510.

53. Qiao, J., D. Cohen, and D. Herzlinger. 1995. The metanephric blastema differentiates into collecting system and nephron epithelia in vitro. Development (Camb.). 121:3207-3214.

54. Santos, O.F.P., E.J.G. Barros, Y.-M. Yang, K. Matsumoto, M. Park, and S.K. Nigam. 1994. Involvement of hepatocyte growth factor in kidney development. Dev. Biol. 163:525-529.

55. Woolf, A.S., M. Kolatsi-Joannou, P. Hardman, E. Andermarcher, C. Moorby, L.G. Fine, P.S. Jat, M.D. Noble, and E. Gherardi. 1995. Roles of hepatocyte growth factor/scatter factor and met in early development of the metanephros. J. Cell Biol. 128:171-184.

56. Kanwar, Y.S., Z.Z. Liu, A. Kumar, J. Wada, and F.A. Carone. 1995 Cloning of mouse c-ros cDNA, its role in development and relationship to extracellular matrix glycoproteins. Kidney Int. 48:1646-1659.

57. Schuchardt, A., V. D'Agati, L. Larsson-Blomberg, F. Costantini, V. Pachnis. 1994. Defects in the kidney and enteric nervous system of mice lacking the tyrosine kinase receptor Ret. Nature (Lond.). 367:319-320.

58. Threadgill, D.W., A. Dlugosz, L.A. Hansen, T. Tennenbaum, U. Lichti, D. Yee, C. LaMantia, T Mourton, K. Herrup, R.C. Harris, J.A. Barnard, S.H. Yuspa, R.J. Coffey, and T. Magnuson. 1995. Targeted disruption of mouse EGF receptor: effect of Genetic Background on mutant phenotype. Science (Wash. DC). 269:230-234.

59. Sariola, H., M. Saarma, K. Sainio, U. Arumae, J. Palgi, A. Vaatokari, I. Thesleff, and A. Karavanov. 1991. Dependence of kidney morphogenesis on the expression of nerve growth factor receptor. Science (Wash. DC). 254:571573

60. Mugrauer, G., and P. Ekblom. 1991. Contrasting expression patterns of three members of the $m y c$ family of protooncogenes in the developing and adult mouse kidney. J. Cell Biol. 112:13-25.

61. Woolf, A.S. 1995. Clinical impact and biological basis of kidney malformations. Semin. Nephrol. 15:361-372. 